\title{
Penciptaan Naskah Drama Pemberontakan Sisifus
}

\author{
RANO SUMARNO ${ }^{1}$ \\ Jurusan Teater, Fakultas Seni Pertunjukan, Institut Seni Indonesia Yogyakarta
}

\begin{abstract}
The Rebellion of Syssiphus. The Rebellion of Syssiphus play script is an effort to response suicide phenomenon in Indonesia. Joining two different social lives among human life in Indonesia and Greek mythology constructs this creation as a surrealism play script. The purpose of this creation is: 1) to create a joint script of two different realms between Sissyphus' life and recent reality of Indonesian people's life in surrealist plot, (2) to produce a script constantly contextual with man's problem in life, (3) to enrich Indonesia Drama documentation through a script with high motivational contents as an alternative of destiny. As a anti-suicide campaign for Indonesians, the author invokes a brilliant thinking of existentialist philosopher, Albert Camus, within the script to be performed and watched. The implementation is not wholesome, but adapting Pancasila values. Therefore, this script is important as a reference for students who teach and perform absurd scripts. Most drama observers say that the emergence of absurd script proposed by group of dramatist in 1950's could not be released from Camus' thought.
\end{abstract}

Key words: Suicide, sissyphus, script

\section{Pendahuluan}

Sebuah survei Lembaga Ilmu Penelitian Indonesia (LIPI) akhir tahun 2008 menerangkan bahwa jumlah penduduk Indonesia yang meninggal dunia dengan cara bunuh diri mencapai 50 ribu orang pertahun, atau jika dirata-ratakan angka ini menunjukan bahwa setiap 10 menit satu orang penduduk Indonesia melakukan bunuh diri. Sungguh merupakan hitungan matematis yang miris sekaligus ironis bagi sebuah negara yang memiliki landasan berkeTuhanan Yang Maha Esa. Berdasarkan data dari direktur World Health Organization (WHO) bidang kesehatan mental dan kekerasan, Benedetto Saraceno pada 2005, jumlah rata-rata penduduk Indonesia yang meninggal akibat bunuh diri mencapai 24 orang dari 100 ribu penduduk. Jumlah itu lebih besar empat kali pada jumlah yang terdata di kamar jenazah yaitu enam dari 100 ribu kematian. Meski hampir semua agama di dunia ini mengutuk manusia yang melakukan tindakanyang mendzolimi diri sendiri- itu, namun bunuh diri seakan menjadi populer sebagai solusi untuk sebagian orang dalam mengakhiri kehidupan yang penuh dengan kepenatan masalah. Jika dihitung secara global, sebanyak 1 juta orang di dunia yang bunuh diri setiap tahunnya. Berarti ada satu orang setiap 40 detik yang bunuh diri. Tindakan bunuh diri merupakan satu dari tiga penyebab kematian tertinggi pada 15-34 tahun. Percobaan bunuh diri mencapai 20-50 juta pertahun (World Health Organization, 2005).

Berangkat dari data yang mengkhawatirkan itu perlu sebuah tindakan nyata dari pemerintah dan ilmuwan dengan bidangnya masing-masing yang mampu menghambat peningkatan angka tersebut. Bunuh diri memang bukan masalah baru, tindakan ini sudah muncul sejak berabadabad yang lalu. Bahkan di negara matahari terbit, bunuh diri menjadi sebuah tradisi yang kemudian dikenal dengan istilah Harakhiri. Bunuh diri saat ini tidak hanya dilakukan oleh seorang diri saja, namun banyak yang melakukannya secara masal. Di Indonesia bunuh diri sudah tidak mengenal batas usia. Mulai dari usia manula hingga anak yang masih duduk di sekolah dasar banyak yang melakukan bunuh diri. Faktor yang melatar belakangi penyebab bunuh diri di Indonesia

1 Alamat korespondensi: Prodi Teater ISI Yogyakarta, Jln. Parangtritis Km. 6,5 Sewon, Yogyakarta, Tlp. 0274-375380, e-mail: rano.teater@gmail.com 
beragam, mulai dari masalah ekonomi, rumah tangga, bahkan masalah percintaan. Indonesia memiliki banyak faktor gangguan jiwa penyebab bunuh diri. Jumlah pengangguran yang mencapai 40 juta jiwa orang, kemiskinan, kesulitan ekonomi, mahalnya biaya hidup, penggusuran, lingkungan psikososial yang parah, kesenjangan yang begitu besar, pekerja migran dan pasien gangguan mental tidak tertangani secara optimal mudah memicu gangguan jiwa (Ahmad Prayitno, 2007). Dengan demikian maka diperkirakan angka bunuh diri di Indonesia akan semakin meningkat seiring dengan multi krisis yang terus menerus melanda negara ini.

Pada dasarnya setiap individu yang melakukan bunuh diri adalah dikarenakan mereka tidak memahami kehidupan dunia. Ada banyak kebenaran, tetapi tidak ada yang benar; ada banyak deskripsi mengenai bagian-bagian, tetapi tidak ada penjelasan mengenai keseluruhan. Semua ilmu pengetahuan berhenti pada hipotesis. Namun masih ada perasaan tentang absurditas karena dunia adalah sesuatu yang tidak terjelaskan (Vincen Martin, 2001:51). Menurut Albert Camus, salah satu tokoh filsafat eksistensialis mengatakan, bahwa bunuh diri terbagi menjadi dua macam, yaitu; bunuh diri fisik dan bunuh diri filsafat. Bunuh diri fisik adalah mengakhiri kehidupan seseorang sebagaimana yang diakui orang bahwa hidupnya sudah terlalu susah, bahwa hidupnya sudah tidak lagi berharga. Menyadari tidak adanya alasan untuk hidup, melihat kebodohan hidup sehari-hari, dan yakin bahwa itu benar-benar merupakan penderitaan yang gagal, orang lantas memutuskan bahwa penyelesaian absurditas ini adalah dengan mengakhiri hidupnya. Dari sudut pandang filsafat, Camus menganalogikan bahwa seorang filosof sangat sadar tentang absurditas dan ketidakrasionalan eksistensi; tetapi kemudian karena ada beberapa simpul pikiran, beberapa putaran keinginan, dan perubahan imajinasi, ia menemukan makna dan rasionalitas dalam dunia ini. Dimulai dengan suatu filsafat tentang absurditas, filosof jenis ini akan berakhir dengan rasionalitas. Tetapi hanya dengan menolak, tidak berbuat, dengan membunuh sikap folosofinya yang asli (Vincen Martin, 2001:55).

Menyikapi masalah semacam itu, Albert Camus sejak bertahun-tahun yang lalu menegaskan bahwa tidaksatupun bentukbunuhdirimerupakan sebuah jawaban. Jawaban yang tepat dalam menghadapi berbagai masalah kehidupan adalah dengan pemberontakan. Kenapa harus memberontak? Karena kehidupan ini baik. Pemberontakan yang dimaksud oleh Camus adalah pemberontakan yang lunak, artinya; manusia harus menantang kepada nasibnya tetapi tidak dengan kekerasan dan menghancurkan orang lain. Manusia yang absurd adalah manusia yang megerti arti absurditas itu, manusia yang tidak lari dari absurditas tetapi selalu menjaganya di dalam kesadarannya; inilah manusia yang menantang, inilah manusia pemberontak. Manusia dalam pemberontakan tertarik pada realitas yang mengangkatnya karena dirinya tidak bisa memahaminya. Tapi dia jauh dari sikap mengalah, jauh dari sikap melarikan diri. Dia berdiri menantang, berjuang tanpa harapan. Dia tahu bahwa dirinya akan hancur tetapi tetap melawan, dia ingin hidup dan tidak mau menyerah. Pemberontakan itu memberi nilai pada kehidupan dan mengembalikan kebesaran pada eksistensi manusia (Vincen Martin, 2001:5657).

Absurditas tidak membebaskan, tetapi mengikat. Ia tidak memberi wewenang untuk berbuat apa saja. Segalanya boleh dilakukan tidak berarti bahwa tidak ada satupun yang dilarang. Absurditas hanya memberi kesamaan nilai kepada akibat-akibat dari tindakan-tindakannya. Ia tidak menyuruh melakukan kejahatan karena itu kekanak-kanakan (Camus, 1999:85)

Selanjutnya Camus menawarkan sebuah konsep dalam menghadapi kehidupan absurd ini dengan cerita Sisifus. Dalam perjuangannya mempertahankan hidup, Camus mengajak setiap manusia untuk tidak menyerah, tetap tegar dan tidak melakukan bunuh diri. Meski Sisifus adalah sebuah mitologi kolot dari Yunani, namun pelajaran yang maha kaya ini akan selalu kontekstual selama dunia ini dihuni oleh manusia yang bernyawa. Di mata dewa, Sisifus adalah orang terhukum, durhaka dan berbahaya. Keberanian dan cara berfikirnya yang kritis dianggap bisa mengganggu ketentraman manusia dan para dewa. Sebuah ganjaran harus diterima oleh Sisifus ini dengan menjadi pekerja neraka yang tak berguna. Diceritakan bahwa Sisifus telah bersikap meremehkan terhadap para dewa, dengan membocorkan rahasia mereka. Syahdan, Ejin wanita cantik setingi langit yang merupakan putri Asop, diculik oleh Jupiter. 
Maka demi kecintaannya kepada sang putri, murkalah Asop dan meminta pertolongan kepada Sisifus. Berhubung Sisifus mengetahui hal-ihwal penculikan Ejin, Sisifus menawarkan kepada Asop untuk mengatakan apa yang diketahuinya. Sisifus meminta syarat untuk diberikan berkah air kepada benteng Korinthus. Sisifus memilih berkah air meskipun harus menerima kemarahan para dewa. Oleh karena kelancangannya itu dihukumlah dia menjadi penghuni neraka.

Di medan hukuman inilah justru Sisifus memberikan pelajaran kepada manusia di jagat raya ini untuk bisa memaknai hidup. Sesosok tubuh yang meregang dengan balutan keringat mengangkat batu raksasa dari kaki gunung menuju puncaknya. Tangannya yang jauh lebih kecil dari batu itu mendorong dan mengelindingkan diri di lereng terjal tiada akhir. Tampaklah raut wajah dengan sorot mata yang tajam, ketegangan menyelimuti hatinya yang menyala, pipinya yang menempel pada batu berlumur tanah, ditopangnya bongkahan padat itu dengan bahunya, kakinya merayap memanjat lambat menuju puncak bukit harapan. Perlahan tapi pasti dipenghujung waktu yang berlalu, sampailah Sisifus pada tujuannya, membawa batu itu menuju perintah dewa. Lalu beberapa saat setelah nafasnya terhirup, diluncurkannya batu keparat itu kedunia bawah menuju tempat di mana dia harus kembali mendorong nasibnya itu naik kepuncak. Sisifus berjalan di belakang batu yang terjatuh itu, langkahnya pasti bersama tekad untuk siap bekerja kembali.

Albert Camus mengajak manusia untuk membayangkan bahwa kehidupan manusia di dunia ini adalah seperti hidupnya Sisifus. Setiap hari manusia melakukan rutinitas kehidupan yang menjemukan. Apa yang dilakukan hari ini hampir sama dengan apa yang dilakukan hari kemarin, begitu terus sampai berbulan-bulan bahkan bertahun-tahun. Sampai suatu waktu tiba-tiba manusia dihadapkan dengan berbagai masalah; kesedihan, bencana, persaingan, pengkhianatan, beban hidup, dll, yang membuat manusia terlempar ke sudut tekanan jiwa dan mengakibatkan stress. Akan tetapi sebesar apapun masalah yang dihadapi, itulah kenyataan hidup ini sebagaimana batu raksasa yang menjadi nasibnya Sisifus. Camus mengajak manusia untuk tetap bertahan hidup di tengah badai cobaan yang menerpa dan tidak lari dari kenyataannya, menjadi manusia yang menantang dan pemberontak. Camus menempatkan Sisifus sebagai pahlawan absurd dan menyerukan manusia untuk belajar darinya. Belajar untuk jauh dari sikap mengalah, bertahan hidup dan tidak menyerah, tidak lari dari kenyataan apalagi memilih bunuh diri sebagai solusi permasalahan. Karena semakin bisa mengatasi masalah dan cobaan maka sesungguhnya manusia menjadi lebih kuat dari cobaan itu sendiri. Seperti itulah Sisifus, yang mampu mengangkat batu ke puncak gunung, sampai waktu yang berulang kali maka tubuh Sisifus menjadi lebih kuat dari batu itu.

Berangkat dari sebuah mite yang monumental dan syarat dengan nilai motivasi ini, penulis menuangkannya menjadi sebuah karya seni dalam bentuknaskahdramayangberjudulPemberontakan Sisifus (PS). Naskah drama ini menjadi penting karena selain dimanfaatkan untuk meningkatkan motivasi masyarakat umum juga sebagai acuan pembelajaran bagi mahasiswa jurusan teater yang akan mengkaji dan mementaskan naskah-naskah absurd. Hampir semua pengamat seni drama mengatakan kemunculan naskah-naskah absurd yang digagas oleh sekelompok teaterawan pada dekade 1950an tidak lepas dari pengaruh Camus dengan esainya yang berjudul The Myth of Sisyphus. Diduga pembicaraan sekelompok teaterawan muncul pada dekade 1950an dengan esai Camus. Mungkin pula dapat dikatakan bahwa dugaan itu juga didasarkan pada rumusan Esslin (1960) bahwa kelompok itu kemudian disebut sebagai teaterawan Theatre of The Absurd. Hampir semua ahli seni drama menyebutkan bahwa Samuel Beckett, Eugene Ionesco, Arthut Adamov, Jean Genet, yang berdomisili di Perancis, juga Harold Pinter di Inggris dan Edward Albee di Amerika adalah tokoh penting gerakan teaterawan 1950an itu (Bakdi Soemanto, 2001:59)

Naskah drama yang penulis ciptakan tentu saja tidak melulu mengangkat budaya bangsa Yunani kuno. Alur cerita ini lebih dominan menggambarkan beragam masalah yang terjadi di Indnesia. Tokoh-tokoh yang muncul adalah realita sosial yang akrab dengan keseharian kita. Bermacam lapisan masyarakat dengan profesinya masing-masing dan masalahnya masing-masng akan melengkapi untuk lebih mengakrabkan dengan apresiasi masyarakat Indonesia. Sedang dunia Sisifus dengan imajinasi budaya Yunaninya 
akan muncul dalam pengadegan sebuah dongengan. Maka suasana kehidupan di Indonesia akan saling bergantian muncul bersama suasana kehidupan di Yunani.

Menggabungkan dua kehidupan sosial yang berbeda dalam satu naskah tentu bukan pekerjaan yang mudah, bagaimana gejala sosial yang tengah terjadi di Indonesia sekarang ini bisa berdampingan bersama saat kondisi dalam kisah Sisifus terjadi menyatu dalam satu pertunjukan yang sama. Terlebih naskah ini diharapkan bisa mewadahi beragam keluhan masyarakat atas masalah-masalahnya dan menjadi sebuah motivator bagi yang membacanya, bagi sutradara yang menggarapnya menjadi seni pertunjukan teater, bahkan bagi para penonton pertunjukannya. Maka sebagai perumusan ide untuk lebih memfokuskan penciptaan naskah drama ini penulis menghadirkan beberapa pertanyaan sebagai berikut; Bagaimanakah bentuk naskah yang akan tercipta dengan menempatkan logika mitologi Yunani dalam kisah Sisifus bisa masuk kedalam kehidupan sosial di Indonesia? Bagaimanakah bentuk naskah yang tercipta bisa menampung berbagai macam keluhan yang terjadi di tengah masyakarat Indonesia? Bagaimanakah bentuk naskah yang tercipta bisa menjadi motivasi kepada masyarakat Indonesia untuk bisa bertahan hidup di tengah bermacam cobaan ?

\section{Hasil dan Pembahasan}

Dalam perkembangannya dunia teater tidak lagi terpenjara dalam aliran realis yang selalu memamerkan realita kehidupan seperti pada awalawal kemunculannya. Gerakan kreatifitas yang dipengaruhi oleh sosio-politik telah mendorong bergesernya aliran mulai dari klasik, realis, surealis dan seterusnya berkembang hingga muncul aliran kontemporer. Aliran surealis pertama kali muncul adalah terjadi sebelum perang dunia kedua ketika para sastrawan Eropa berjuang melawan dominasi kaum borjuis terhadap kemapanan. Guillaume Apollinaire, pencipta istilah surealisme (super realisme atau melampaui kenyataan) adalah sebuah suara berontak yang diteriakkan oleh sekawanan sastrawan (dan kemudian seniman rupa) untuk mengguncang dunia borjuis Eropa yang mereka anggap mapan, mandeg, dan mengidap penyakit puas diri (Hasif Amini:2006).
Perbedaan yang mendasar antara aliran realisme dan surealisme dalam dunia sastra dan teater adalah terletak pada bentuk pengemasannya. Dalam surealisme kita akan menemukan lompatan-lompatan fikiran dari alam sadar manusia menuju alam bawah sadar manusia. Lompatan tersebut menjadi sebuah estetis yang unik karena dunia nyata dan dunia mimpi atau khayalan menyatu tanpa adanya selaput yang memisahkannya. Hal ini tentu saja bukan berarti surealisme tidak memiliki kekurangan, karena dalam surealisme tata bahasa menjadi tidak terperhatikan dan menjadi rumit untuk dicerna. Menurut HB. Jassin, cerita yang surealistis adalah menangkap kehidupan pada suatu saat dalam keseluruhannya, pikirannya meloncat-loncat dengan cepat, tata bahasa jadi tidak terperhatikan dalam ketergesaan ingin menangkap semuanya (Abdul Wachid, 2002: 45). Surealisme merupakan sebuah alat untuk menggabungkan alam sadar dan alam tidak sadar manusia. Kenyataan dalam surealisme adalah kenyataan dimana alam sadar dan tidak sadar manusia berhimpit dan menyatu dalam sebuah kenyataan baru (Eric Sasono: 2005). Aliran surealisme adalah upaya manusia untuk menerobos batas kenyataan dan imajiner. Surealisme mendasarkan pada realitas yang superior dari kebebasan asosiasi yang telah lama ditinggalkan, dari keserbabisaan mimpi, pada pemikiran yang otomatis tanpa kontrol kesadaran kita (Soedarso, 2000:133). Surealisme dalam dunia sastra mengarah kepada pemakaian bentuk estetika surealisme (surealisme-estetis), yakni mempertemukan antara pencitraan alam nyata dan alam angan dalam keseruangan dan kesewaktuan. Realitas yang terjadi sebagai hasil seni surealisme adalah berbaurnya antara realitas formal dan realitas imajiner (Abdul Wachid, 2002:44).

Pemikiran-pemikiran mengenai aliran realisme tersebut telah mempengaruhi penulis dalam penciptaan naskah dramaini. Dua duniakehidupan yang terjadi antara realitas kehidupan masyarakat Indonesia jaman sekarang dengan mitologi Yunani kuno yang menceritakan kisah manusia dengan para dewa dikemas menjadi kesatuan cerita. Peleburan dua kehidupan ini terkemas di mana dunia Yunani kuno meruang menjadi imajinasi tokoh-tokoh masyarakat Indonesia jaman sekarang sebagai sebuah dongengan. Ketika tokoh Pak 
Dalang memberikan ceramah kepada orang-orang Indonesia yang berniat akan melakukan bunuh diri, itu adalah dunia nyata yang terjadi sesunggunya. Tetapi ketika Pak Dalang bercerita tentang kisah Sisifus yang terjadi pada jaman Yunani Kuno dan kemudian kejadian itu dimunculkan sebagai bagian dari adegan panggung, maka bentuk itu telah menjadi surealisme. Contoh adegan tersebut dapat kita temui dalam naskah PS sebagai berikut: Pak Dalang : Baiklah kalian semua dengarkan ceritaku ini. Akan aku kisahkan perjalanan hidup seorang manusia Absurd yang bernama Sisifus.

Semua : Sisifus ??

Perempuan : Sisifus ?? siapa itu Pak Dalang??

Mahasiswa : Iya namanya aneh.

Pak Dalang : Ini adalah sebuah mite, mitologi tua dari Yunani, kisah manusia perkasa yang kritis dan pemberani. Kepintarannya melebihi para dewa dan kesabarannya melebihi cobaan-cobaannya. Cerita ini diawali ketika Sisifus membuka rahasia penculikan Dewa Zeus kepada putri Egina anak kesayangan Dewa Asopus. Waktu itu.....

(Set berubah, suasana berganti menjadi kehidupan jaman Yunani kuno tempat di mana para dewa hidup. Musik berupa paduan suara)

Paduan Suara: Titah Dewa adalah sabda. Hati yang suci di tanah yang abadi. O, Putri Egina, wanita cantik setinggi langit, menatap gemawan penuh harapan. Hatinya cemas terpancar dari paras, menanti setia datangnya berita. Lihatlah matanya yang memendam Tanya dimanakah dia pujaan hatinya.

Putri Egina : Cahaya yang tenang diujung dedaunan, gelisah yang nyata apakah maknanya? $\mathrm{O}$, suara-suara yang sembunyi di dalam hati, semakin meraja di puncak surgawi. Adakah kisah yang abadi untuk hatiku yang telah lama mati.
Paduan Suara: tak ada cinta yang tak berduka tak ada asmara yang tanpa derita. Sang Dewi gadis yang mempesona sedang dirundung asmara rupanya?

Dalam adegan tersebut jelas telah terjadi lompatan dimensi kehidupan dari jaman sekarang menuju dunia imajiner yang didongengkan oleh tokoh Pak Dalang. Lompatan tersebut bukan hanya merubah suasana, tempat dan waktu saja tetapi terasa dalam gaya bahasa yang dibawakannya. Penulis menciptakan gaya bahasa yang berbeda antara dunia sekarang dan dunia jaman Yunani kuno dalam naskah drama ini yang disebut dengan istilah Etnopuitika. Etnopuitika merupakan satu bentuk pendekatan yang relatif baru dalam khasanah penelusuran jejak seni tradisi. Etnopuitika dapat dipandang sebagai puitikapentas, yang terutama bertujuan mempelajari pentas sastra (lisan) atau verbal art performance, dan bobot serta kedalaman hasil penelitian ini sangat bergantung pada pengetahuan peneliti mengenai budaya lokal (Kadarisman, 2001:1). Hal ini dilakukan penulis saat menggambarkan kehidupan pada jaman sekarang dengan menggunakan bahasa kekinian yang umum dipakai oleh masyarakat Indonesia dalam kesehariannya, tetapi gaya bahasa yang digunakan dalam adegan Yunani kuno menggunakan gaya poetika mirip dengan naskah-naskah aliran klasik. Hal ini untuk membantu mengkontraskan bahwa dalam naskah ini terdapat dua kehidupan dunia yang berbeda, yakni dunia realita dan dunia dongengan. Contoh lain yang menggambarkan lompatan kehidupan dalam naskah PS ini dapat kita temui pada adegan sebagai berikut:

$\begin{aligned} \text { Pujangga : Terus siapa yang membebaskan } & \\ & \text { Dewa Hades dari tangan Sisifus? }\end{aligned}$

Pak Dalang : Karena Dewa Zeus tidak ingin kerajaannya mejadi sepi karena tidak ada yang mati, maka Dewa Zeus mengirim Dewa Ares sebagai Dewa perang untuk membebaskan Dewa Kematian dari tangan penakluknya.

Pekerja : Apa Sisifus tidak takut kalo dia akan diadili lagi oleh para Dewa?

Pak Dalang : Dia sadar kalau dia pasti akan ditangkap dan kembali diadili, 
bahkan dia juga sadar kalau hukuman yang akan dia terima nanti akan lebih berat lagi.

Pemuda : Kalau Sisifus tau kalau dihukum lebih berat lagi kenapa gak dibebasin saja tawanannya?

Pak Dalang : Sisifus bukan manusia penge cut. Dia manusia yang berani menghadapi tantangan dan melawan terhadap segala penyebab kematian. baginya, tetap hidup adalah harga mati. Kalaupun dia harus mati maka dia meminta kepada istrinya untuk tidak mengubur atau membakar jasadnya seperti yang dilaukan manusia lain. Dia malah meminta agar jasadnya dibuang ke tengah-tengah pasar. Biarkan orang-orang menginjaknya, biarkan anjing menyeretnya, biarkan lalat-lalat menggigiti kulitnya...

(Di Kerajaan Korintus terlihat Hades terikat rantai dan bibir terikat tali sehingga tidak bisa bicara. Di dekatnya Sisifus berbicara kepada Merope istrinya)

Paduan Suara: O, raja Korintus manusia pemberani dialah Sisifus. Lihatlah gelisah yang menggunung di matanya karena sikapnya yang menentang Dewa maka hukumanNya pasti tiba. Wahai Sisifus raja kami yang berani. Kami mohon, O raja. Sekali lagi kami memohon padamu.

Sisyfus : Apa yang kau mohonkan padaku? Demi cintaku pada rakyat Korintus segala yang kau minta segera akan kau terima. Demikianlah adanya selama aku bisa.

Paduan Suara: O, Raja yang berbudi luhur kebaikanmu sungguh tak terukur. Rakyat yang dulu kehausan kini tak perlu lagi dirisaukan. Karena kecintaanmu, tiada rakyat yang kelaparan karena mereka kini hidup dengan serba kecukupan. Ternak serta ladang-ladang kami yang gugur kini telah tumbuh dengan subur. Semua ini adalah karena keberanian raja untuk menolong kami rakyat yang jelata.

Sisyfus

: Aku adalah raja kalian. Gelisahlah hatiku jika masih kudengar ada yang kelaparan di negeriku. Telah kumohonkan berkah air suci untuk membasahi negeri ini. Bahkan semua raga ini telah ku relakan untuk rakyat Korintus yang kucintai. Wahai rakyatku yang sentosa, katakanlah apa lagi yang kalian minta?

Sebagai penguatan konsep surealisme dalam naskah PS ini, penulis secara ekstrim mempertemukan tokoh masyarakat Indonesia dengan tokoh-tokoh yang terdapat dalam dunia dongengan Pak Dalang. Pada adegan terakhir ketika Sisifus sedang menjalani hukumanya dengan mengangkat batu ke puncak gunung, tokoh-tokoh masyarakat Indonesia meruang dalam adegan tersebut menjadi satu kesatuan kejadian dan bergantian mengangkat batu tersebut bersama Sisifus. Hal ini dapat kita lihat pada bagian terakhir naskah sebagaiberikut:

Pak Dalang : Sekarang bayangkanlah jika batu itu adalah masalah dan cobaan yang sering datang menghampiri kita. Semakin kita berani menghadapi cobaan itu maka kita akan menjadi lebih besar dari cobaan itu sendiri, sebagaimana Sisifus menjadi lebih besar dari batunya.

Semua : Sisifus menjadi lebih kuat dari batunya. Sisifus menjadi lebih besar dari batunya. Sisifus menjadi lebih mulia dari takdirnya. (semua mendekati Sisifus yang mengangkat batu kemudian mereka bergantian)

Pak Dalang : Pada waktu kembali itulah, yakni pada saat ia mengambil jedah, Sisifus menarik perhatian saya. Sebuah wajah yang menderita begitu dekat dengan batu itu sudah merupakan batu itu sendiri. Saya melihat laki-laki itu turun kembali dengan langkah berat tetapi teratur ke arah siksaan yang tidak ia ketahui kapan akan berakhir. Saat yang bagaikan nafasnya sendiri, 
dan yang pasti kembali lagi seperti halnya kesengsaraannya, saat itu adalah saat kesadaran. Pada setiap saat ketika ia meninggalkan puncak gunung dan sedikit demi sedikit masuk kesarang para Dewa, ia lebih tinggi daripada takdirnya. Ia lebih kuat daripada batunya (Albert Camus).

Dan batu kembali ke jurang menggelundung. Bolak-balik beribu tahun: beribu tahun Sisipus mendorong batu ke puncak gunung kau mendaki dan tergelincir, jatuh dan bangun.

Jatuh dan bangkit di Babel, Sodom dan Gomorah, Auschwitz, Hiroshima-Nagasaki dan Vietnam. Dan dari dasar derita, dengan nafas tersengal kau berseru ke langit: Apakah artinya ini?

Langit menjawabmu dengan biru, dengan bisu. Kau pun bangkit lagi; pucat, berdebu dan luka kembali mendaki dan meman dang Angkasa. Mungkin itulah artinya: Payah dan luka kau tak tunduk (Saini KM)

(suara-suara menghilang seiring dengan Sisifus bersama orangorang ikut menghilang yang tertinggal hanya Pak Dalang dalam kesendirian)

\section{Naskah Sebagai Motivator}

Sebagaimana diungkapkan dalam perumusan ide penciptaan ini, penulis memiliki kegelisahan dalam menciptakan sebuah naskah yang mampu menampung berbagai macam keluhan yang terjadi di tengah masyakarat Indonesia dan menciptakan naskah sebagai motivator bagi masyarakat Indonesia untuk bisa bertahan hidup di tengah bermacam cobaan. Hal ini merupakan respon penulis terhadap meraknya aksi bunuh diri yang terjadi begitu mengerikan di negara ini. Maka dalam penciptaan naskah ini penulis sedapat mungkin memberikan amanat yang bermanfaat untuk diterapkan dalam kehidupan sehari-hari. Setiap naskah memiliki pesan atau amanat yang ingin disampaikan oleh pengarang kepada setiap penikmat naskahnya. Amanat atau pesan dalam sebuah naskah drama adalah hal mendasar yang ingin disampaian oleh seorang pengarang kepada pihak lain, yaitu pembaca, penonton, maupun sutradara beserta timnya. Pendapat klasik mengatakan bahwa karya sastra yang baik selalu memberikan pesan kepada pembaca untuk berbuat baik, pesan ini dinamakan moral atau amanat (Budi Darma, 1984:47).

Dalam hal menampung berbagai macam keluhan yang bersifat psikologis, penulis mencoba mengangkat beragam pertanyaan umum yang diwakilkan pada tokoh-tokoh yang akan melakukan bunuh diri dalam naskah PS ini dan dijawab dengan kalimat inspiratif baik dari penulis maupun kutipan dari para inspirator dunia. Hal ini dapat kita temui dalam adegan sebagai berikut: Pak Dalang : kalian tahukan William Shakes peare? Beliau mengatakan bahwa dalam hidup ini sesungguhnya tak ada yang bisa dikatakan sebagai sesuatu yang baik atau buruk, kecuali pikiran kitalah yang membuatnya seperti itu. Artinya kalo kamu berfikir kamu kalah, berarti kamu sudah kalah. Jika kamu berfikir kamu tidak berani, berarti kamu tidak akan pernah berani. Jika kalian ingin menang tetapi fikiran kalian tidak berisi muatan kemanangan, maka hampir bisa dipastikan kalian tidak akan menemukan kemenangan. Hanya orang-orang yang berfikir menanglah yang akan mendapatkan kemenangan (Amold Palmer)

Pujangga : Lantas apa yang harus kami lakukan untuk meghadapi hari-hari esok, pak Dalang?

Pak Dalang : Cara paling efektif untuk mencapai masa depan yang cerah adalah dengan menghadapi masa kini secara berani (Rollo May). Ketika kamu mengerutkan dahi untuk menatap hari esok, maka berarti kamu juga sedang mengerutkan jiwa menjadi ciut (Waterson Low).

Perempuan : Lalu bagaimana dengan saya pak Dalang? Penyakit yang saya 
derita ini sangat sulit untuk disembuhkan. Apa yang harus saya kerjakan? Saya sudah berusaha mati-matian tapi hasilnya tetap nihil.

Pak Dalang : Kesabaran adalah obat yang pahit tapi akan menjadikan buah yang manis. Bersabarlah dan berusahalah. Kamu tidak sendiri, mintalah bantuan pada keluarga dan saudara-saudaramu.

Perempaun : Tapi saya sudah terlalu banyak meminta bantuan sama orang lain. Saya malu rasanya saya sudah tidak punya harga diri.

Pak Dalang : Mengapa mesti malu? Meminta bantuan kepada orang lain bukanlah tanda kelemahan melainkan kecerdikan.

Karyawan : Saya sudah kehilangan pekerjaan, pak Dalang. Saya ini korban PHK, mesti bagaimana lagi saya membiayai keluarga kalo saya tidak punya pekerjaan? Keadaan ini benar-benar membuat saya stress.

Pak Dalang : Kenapa kamu menyalahkan keadaan yang menimpa diri kamu? Bukankah orang-orang yang sukses di dunia ini adalah orangorang yang bangkit dan mencari keadaan yang diinginkannya. Lalu apabila tidak menemukan keadaan itu maka mereka menciptakan keadaan tersebut (George Bernard Shaw) maka bangkitlah karena niatmu akan mencetak masa depanmu.

Pemuda : Bagaimana dengan aku Pak Dalang? Dokter telah memfonis kalau aku positif mengidap HIV, aku pasti dijauhi orang-orang, aku akan merasa terasing dilingkungan sendiri. Aku hanya tinggal menunggu mati.

Pak Dalang : Hmm, anak muda yang baik. Setiap manusia memiliki tiga hal untuk benar-benar menjadi bahagia di dunia ini; yatu seorang yang dicintai, sesuatu yang dilakukan dan sesuatu yang diharapkan (Torn Bodeft). Setiap orang akan menginginkan panjang umur tapi tak seorangpun menginginkan menjadi tua, (Swift) maka semakin kamu menerima perubahan keadaan maka kamu akan terus hidup, tetapi kalo kamu menolak perubahan maka kamu sebetulnya sudah mati (Ray Norda). Bangkitlah dan lanjutkan hidupmu dengan penuh perjuangan.

Pekerja : Terus bagaimana caranya supaya saya bisa dapat banyak uang, pak Dalang? Saya sudah cape miskin terus, hutang semakin bertumpuk sementara kebutuhan hiduppun semakin tidak terkendali. Saya ingin kaya, saya ingin banyak uang seperti orang-orang yang di sana. Kalo kita gak punya uang percuma saja kita hidup. Selamanya kita hanya menjadi orang pinggiran. Betul gak?

Mahasiswa : Ya betul, aku aja gara-gara gak punya uang kuliahku hampir di DO.

Pak Dalang : Ya memang benar. Kita harus punya uang supaya kita bisa bertahan. Karena kekurangan uang adalah akar dari kejahatan. Tetapi ingat kalo kalian menjadikan uang sebagai Tuhan, maka uang akan terus mengganggu kalian seperti setan (Henry Fielding). Kalo kalian berfokus pada uang maka kalian tidak akan pernah berubah, tetapi kalo kalian berfokus pada perubahan maka kemungkinan besar kalian akan mendapatkan uang (Jack Dixon). Jadi bekerjalah yang giat supaya kalian bisa mendapatkan uang yang banyak.

Mahasiswa : Tapi kenapa aku selalu dihadapi dengan keadaan yang sulit. Meskipun aku sudah berusaha mengatasinya tetapi keadaan sulitlah yang sering aku alami. Tuhan itu tidak adil tidak pernah mengukur kekuatan umatnya. Perasaan sejak pertama aku masuk kuliah cobaan 
hidup yang aku alami selalu berat.

Pak Dalang : Kamu adalah mahasiswa, mestinya kamu mampu memahami setiap makna di balik kesusahan. Ingatlah; akan selalu diperlukan keadaan gawat untuk sebuah kemajuan. Karena Bangsa kita dijajah maka kita memproklamasikan kemerdekaan. Karena ada kegelapan maka manusia membuat lampu. Karena manusia kesulitan berkomunikasi dengan jarak jauh maka dibuatlah Handphone. Karena kamu lapar maka kamu makan. Jadi kalo kamu menemukan kesulitan bukan berarti Tuhan tidak sayang sama kamu melainkan Tuhan menyuruhmu berfikir, karena Tuhan percaya sama kamu kalo kamu mampu melakukannya.

Gadis : Tapi pak Dalang, sebetulnya kami ini bukan orang yang tidak mau berusaha, kami hanya kesal kenapa usaha-usaha kami ini selalu menemukan keagalan.

Pak Dalang : Ingatlah: orang yang bisa mendorong dirinya melangkah maju ketika langkahnya tersandung kerikil dialah orang yang akan memperoleh kemenangan (Roger Bannister) dan tidaklah berdosa orang yang berusaha lalu gagal, dosa itu hanya pantas bagi orang-orang yang tidak pernah mau berusaha (Sue Ellen Fried). Karena gagal juga ada manfaatnya; pertama kalo kalian gagal, maka kalian belajar tentang apa yang tidak seharusnya dilakukan. Kedua kegagalan memberi kalian peluang untuk mencoba pendekatan baru (Roger Von Oech).

Dalam hal menjadikan naskah sebagai motivasi untuk berjuang menghadapi kehidupan, penulis menyisipkan kalmat-kalimat yang bermuatan spirit pada tokoh Pak Dalang. Adegan tersebut dapat dilihat pada contoh dialog sebagai berikut:

Pujangga : Lantas bunuh diri yang mana yang menurut dia baik?
Pak Dalang : Albert Camus, menegaskan bahwa tidak satupun bentuk bunuh diri merupakan sebuah jawaban. akan tetapi jawaban yang tepat dalam menghadapi berbagai masalah kehidupan adalah dengan pemberontakan.

Pekerja : Pemberontakan? Ya saya setuju. Kita harus lakukan pemberontakan dengan menghancurkan gedunggedung pemerintah dan membakar fasilitas umum. Allahuakbar.

Pak Dalang : Goblok.., bukan pemberontakan yang kaya gitu.

Semua : Ahahaha...,

Gadis : Sok tahu sih..,

Pekerja : Oh., terus pemberontakan yang kaya gimana dong pak Dalang?

Pak Dalang : kenapa kita harus memberontak? Karena kehidupan ini baik. Pemberontakan yang dimaksud oleh Albert Camus adalah pemberontakan yang lunak, artinya; manusia harus menantang kepada nasibnya tetapi tidak dengan kekerasan dan menghancurkan orang lain. Manusia yang absurd adalah manusia yang megerti arti absurditas itu, manusia yang tidak lari dari absurditas tetapi selalu menjaganya di dalam kesadarannya; inilah manusia yang menantang, inilah manusia pemberontak. Manusia dalam pemberontakan tertarik pada realitas yang mengangkatnya karena dirinya tidak bisa memahaminya. Tapi dia jauh dari sikap mengalah, jauh dari sikap melarikan diri. Dia berdiri menantang, berjuang tanpa harapan, dirinya tahu bahwa dirinya akan hancur, tetapi dia tetap melawan, dia ingin hidup dan tidak mau menyerah. Pemberontakan itu memberi nilai pada kehidupan, mengembalikan kebesaran pada eksistensi manusia.

Kalimat-kalimat penyemangat dalam naskah ini tidak hanya penulis titipkan pada tokoh Pak 
Dalang akan tetapi juga pada tokoh Sisifus yang terjadi dalam dongengan. Hal ini dapat dilihat pada contoh dialog ketika Sisifus berdiskusi dengan para rakyat Korintus dan dialog Sisifus dengan istrinya, sebagai berikut:

Sisifus : Demi hidup yang aku jalani dan demi lapar serta haus yang kalian hadapi, tak perlulah kalian risaukan tentang segala yang aku deritakan. Nikmatilah segala yang ada dengan kecukupan. Dan lanjutkan hidup kalian dengan segenap perjuangan.

Paduan Suara: O, Raja yang mulia. Apalah artinya kami hidup dengan kecukupan tetapi kami harus kehilangan Raja yang penuh dengan kecintaan. Biarlah kami kembali kekurangan, biarlah kami kembali kelaparan asalkan engkau terbebas dari hukuman Dewa yang mengerikan.

Sisifus : Apa maksud kalian?

Paduan Suara: Lepaskanlah Hades sang Dewa kematian, lalu memohonlah ampun kepada Jupiter dan mengaku bersalah serta mintalah kemurahan hatiNya, semoga kebebasan akan segera engkau dapatkan.

Sisifus : Demi Korintus, demi dunia, dan demi segenap manusia, aku berani menentang takdir Dewa atas segala ketidak adilannya. Tak ada lagi yang harus kalian takutkan. Berontaklah kepada nasib kalian. Maka kalian akan ada dalam kehidupan. Kita semua pada akhirnya akan hancur remuk sampai melebur, tetapi berdirilah kokoh pada kaki kalian, hadapi segala ujian, jangan pernah menyerah untuk sebuah kematian, karena hidup harus terus dilanjutkan, meski maknanya tak pernah kita temukan.

Merope : Paduka Raja. Telah kau khianati sumpah Dewa. Kemudian kau selamatkan manusia dari bencana kematian, kau culik Dewa Hades lalu kau jerat hingga tak berdaya. Kau berani menghadapi siksaan tapi kau tak berfikir aku yang akan mengalami kemalangan.

Sisifus : Merope istriku yang setia. Jika saat ini kau mengalami kesenangan tentu setelahnya kau akan mendapatkan kemalangan. Begitu juga sebaliknya, jika kau mengalami kemalangan maka setelahnya akan berujung dengan kesenangan. Apa yang kau takutkan tak akan pernah kau temukan selama kau yakin bahwa kehidupan harus terus diperjuangkan.

Merope : Kau dicinta bukan hanya karena aku tetapi juga karena rakyatmu.

Sisifus : Semua diantara kita pada waktunya pasti akan mati, dan tak ada sedikitpun yang harus kita takuti. Maka berjuanglah seakan-akan kita tidak akan pernah mati.

Merope : Paduka Raja. Jika kau akan disiksa para Dewa maka aku akan bersamamu dengan setia.

Sisifus : Merope istriku yang setia. Bersumpahlah bersama musim yang terus berganti. Kau akan tetap hidup menebarkan kedamaian kepada rakyat meski jasad dan rohmu tidak lagi melekat. Ajarkan pada mereka tentang nikmatnya kehidupan, indahnya alam semesta dan sejuknya air yang mengalir. Kabarkan kepada mereka bahwa keputusasaan bukanlah jalan untuk mengakhiri permasalahan.

Merope : Aku dan rakyatmu akan melanjutkan apa yang kau perjuangkan.

Sisifus : (memeluk) Merope.., dunia juga akan mengenangmu sebagai lambang kesejukan seperti telah kau sejukkan hatiku.

Diakhir pertunjukan penulis mengutarakan amanat inti dari pemikiran Albert Camus dalam filosofi mite Sisifus yang diucapkan oleh tokoh Pak Dalang. Amanat itu adalah mengajak kepada manusia untuk berjuang mempertahankan kehidupan dengan kesetiaan yang tinggi. Mengajak untuk mencitai alam dengan memeliharanya dan merawatnya karena semua itu baik adanya. 
Albert Camus mengajak kepada manusia untuk tetap berbahagia meskipun cobaan-cobaan yang jalani teramat berat untuk dihadapi seperti halnya Sisifus yang mengangkat batu besarnya. Kalimat tersebut dijadikan penutup pertunjukan, sebagai berikut.

Pak Dalang : Pada waktu kembali itulah, yakni pada saat ia mengambil jedah, Sisifus menarik perhatian saya. Sebuah wajah yang menderita begitu dekat dengan batu itu sudah merupakan batu itu sendiri. Saya melihat laki-laki itu turun kembali dengan langkah berat tetapi teratur kearah siksaan yang tidak ia ketahui kapan akan berakhir. Saat yang bagaikan nafanya sendiri, dan yang pasti kembali lagi seperti halnya kesengsaraannya, saat itu adalah saat kesadaran. Pada setiap saat ketika ia meninggalkan puncak gunung dan sedikit demi sedikit masuk kesarang para Dewa, ia lebih tinggi daripada takdirnya. Ia lebih kuat daripada batunya.

Pak Dalang : Saudara-saudra. Saya tinggalkan Sisifus di kaki gunung. Kita selalu menemukan kembali beban kita. Namun Sisifus mengajarkan kesetiaan lebih tinggi yang menyangkal para Dewa dan mengangkat batubatu besar. Ia juga menilai semua baik adanya. Alam ini, yang semenjak itu tak bertuan lagi, tidak tampak gersang ataupun tak berguna. Setiap butiran batu itu, setiap kilau mineral dari gunung yang penuh dengan malam itu, membentuk sebuah dunia tersendiri. Perjuangan kepuncak gunung itu sendiri cukup untuk mengisi hati seorang manusia. Kita harus membayangkan bahwa Sisifus berbahagia. Selamat malam.

\section{Penutup}

Dalam penciptaan naskah drama ini penulis telah mendapatkan beberapa kesimpulan sebagai penutup hasil penciptaannya, diantaranya sebagai berikut; pertama, untuk mewadahi kegelisahan penulis dalam menyatukan dua latar kejadian yang berbeda menjadi satu kesatuan naskah maka bentuk yang dihasilkan adalah naskah surealisme. Hal ini ditandai dengan penyatuan kehidupan latar masyarakat Indonesia jaman sekarang dengan latar mitologi Yunani kuno yang menjadi satu kesatuan sebagai dongengan.

Kedua, untuk memberikan motivasi kepada apresiator naskah ataupun apresiator pertunjukannya, penulis dapat mengutip ucapan-ucapan penting dari tokoh dunia yang bisa dititipkan pada tokoh-tokoh tertentu. Seperti halnya dalam naskah PS ini, penulis mengutip kalimat-kalimat yang memiliki muatan inspiratif pada tokoh Pak Dalang yang disampaikan kepada tokoh orangorang yang merasa kehilangan rasa kepercayaan diri dalam melanjutkan kehidupannya. Hal ini tidak melemahkan penulis dalam hal originalitas karya melainkan ciri sebuah karya yang ilmiah.

Ketiga, untuk mengkampanyekan anti bunuh diri kepada masyarakat Indonesia, penulis mengangkat pemikiran tokoh filsafat eksistensialis Albert Camus untuk dituangkan dalam naskah drama. Dalam penerapan pemikiran tersebut tentu saja penulis tidak mengambil ajarannya secara keseluruhan karena ada hal-hal yang harus disesuaikan dengan tradisi dan budaya Indonesia.

\section{Kepustakaan}

Aditya. 2009. Kata-Kata Super Peledak Motivasi. Yogyakarta: Grha Pustaka.

Amini, Hasif. 2006. Surealisme. Jakarta: Kompas.

Anwar, Chairul. 2005. Drama, Bentuk Gaya dan Aliran. Yogyakarta: Elkapi.

Camus, Albert. 1999. Mite Sisifus Pergulatan Dengan Absurditas. Terj. Apsanti D. Jakarta: PT Gramedia Pustaka Utama.

Darma, Budi. 1984. Sejumlah Esai Sastra. Jakarta: PT. Karya Unipress.

Esslin, Martin. 2008. Teater Absurd. Terj. Abdul Mukhid. Mojokerto: Pustaka Banyumili.

Gie, The Liang. 2004. Filsafat Seni Sebuah Pengantar. Yogyakarta: Pusat Belajar Ilmu Bergun.

Hamersma, Harry. 2008. Pintu Masuk ke Dunia Filsafat. Yogyakarta: Pustaka Filsafat.

Harimawan, RMA. 1988. Dramaturgi. Bandung: Remaja Rosdakarya. 
Hasanudin. 1996. Drama Karya Dalam Dua Dimensi Kajian Teori, Sejarah Dan Analisis. Bandung: Angkasa.

Keliat. 1993. Seri Keperawatan: Tingkah Laku Bunuh Diri. Jakarta: Penerbit Buku Kedokteran EGC.

Langer, Suzane K. 2006. Problematika Seni. Terj. FX. Widaryanto. Bandung: Sunan Ambu Press.

Martin, Vincent, O.P. 2001. Filsafat Eksistensialisme. Terj. Taufiqurrahman. Yogyakarta: Pustaka Pelajar.

Nalan, Arthur S., Benny Yohanes., dan Suyatna Anirun. 1998. Mencipta Teater. Bandung: CV. Geger Sunten.
Russell, Bertand. 2007. Sejarah Filsafat Barat. Terj. Sigit Jatmiko, dkk. Yogyakarta: Pustaka Pelajar.

Sanjaya, IGN Arya. 2009. Melakoni Teater; Sepilahan Tulisan Tentang Teater. Bandung: Studiklub Teater Bandung.

Sasono, Eric. 2005 . Banyu Takut Air. Jakarta: Kompas.

Soemanto, Bakdi. 2001. Jagat Teater. Yogyakarta: Penerbit Media Pressindo.

Wachid, Abdul B.S, 2002. Religiositas Alam: Dari Surrealisme ke Spiritualisme D. Zamawi Imron. Yogyakarta: Gama Media.

Yudiaryani. 2002. Panggung Teater Dunia. Yogyakarta: Pustaka Gondosuli. 